Article

\title{
Appropriate Reference Genes for RT-qPCR Normalization in Various Organs of Anemone flaccida Fr. Schmidt at Different Growing Stages
}

\author{
Zeying Zhao ${ }^{1,2,3}$, Hanwen Zhou ${ }^{1}$, Zhongnan Nie ${ }^{4}{ }^{\oplus}$, Xuekui Wang ${ }^{1}$, Biaobiao Luo ${ }^{1}$, Zhijie $\mathrm{Yi}^{1}{ }^{1}, \mathrm{Xinghua} \mathrm{Li}{ }^{1}$, \\ Xuebo $\mathrm{Hu}^{1}$ and Tewu Yang ${ }^{1, *}$
}

1 MOA Key Laboratory of Crop Ecophysiology and Farming System in the Middle Reaches of the Yangtze River, College of Plant Sciences and Technology, Huazhong Agricultural University, Wuhan 430070, China; zhaozeyingme@163.com (Z.Z.); zhouhanwen1990@126.com (H.Z.); wang-xuekui@mail.hzau.edu.cn (X.W.); luo_piaopiao@163.com (B.L.); yizhijie11@163.com (Z.Y.); lixh199015@163.com (X.L.); xuebohu@mail.hzau.edu.cn (X.H.)

2 Northwest Institute of Eco-Environment and Resources, Chinese Academy of Sciences, Lanzhou 730030, China

3 University of Chinese Academy of Sciences, Beijing 100049, China

4 Department of Jobs: Precincts and Regions, Private Bag 105, Hamilton, VIC 3300, Australia; zhongnannie@gmail.com

* Correspondence: yangtewu@mail.hzau.edu.cn; Tel.: +86-132-9659-9563

\section{check for}

updates

Citation: Zhao, Z.; Zhou, H.; Nie, Z.; Wang, X.; Luo, B.; Yi, Z.; Li, X.; Hu, X.; Yang, T. Appropriate Reference Genes for RT-qPCR Normalization in

Various Organs of Anemone Flaccida Fr. Schmidt at Different Growing Stages. Genes 2021, 12, 459. https://doi.org/ 10.3390/genes12030459

Academic Editors:

Christian Chevalier and

Benoît Lacombe

Received: 19 February 2021

Accepted: 17 March 2021

Published: 23 March 2021

Publisher's Note: MDPI stays neutral with regard to jurisdictional claims in published maps and institutional affiliations.

Copyright: (c) 2021 by the authors. Licensee MDPI, Basel, Switzerland. This article is an open access article distributed under the terms and conditions of the Creative Commons Attribution (CC BY) license (https:/ / creativecommons.org/licenses/by/ $4.0 /)$.
Abstract: Anemone flaccida Fr. Schmidt is a traditional medicinal herb in southwestern China and has multiple pharmacological effects on bruise injuries and rheumatoid arthritis (RA). A new drug with a good curative effect on RA has recently been developed from the extract of A. flaccida rhizomes, of which the main medicinal ingredients are triterpenoid saponins. Due to excessive exploitation, the wild population has been scarce and endangered in a few of its natural habitats and research on the cultivation of the plant commenced. Studies on the gene expressions related to the biosynthesis of triterpenoid saponins are not only helpful for understanding the effects of environmental factors on the medicinal ingredient accumulations but also necessary for monitoring the herb quality of the cultivated plants. Reverse transcription quantitative polymerase chain reaction (RT-qPCR) as a sensitive and powerful technique has been widely used to detect gene expression across tissues in plants at different stages; however, its accuracy and reliability depend largely on the reference gene selection. In this study, the expressions of 10 candidate reference genes were evaluated in various organs of the wild and cultivated plants at different stages, using the algorithms of geNorm, NormFinder and BestKeeper, respectively. The purpose of this study was to identify the suitable reference genes for RT-qPCR detection in A. flaccida. The results showed that two reference genes were sufficient for RT-qPCR data normalization in A. flaccida. PUBQ and ETIF1a can be used as suitable reference genes in most organs at various stages because of their expression stabilitywhereas the $P U B Q$ and $E F 1 A$ genes were desirable in the rhizomes of the plant at the vegetative stage.

Keywords: Anemone flaccida Fr. Schmidt; reference gene; data normalization; RT-qPCR; medicinal herb

\section{Introduction}

Anemone flaccida Fr. Schmidt, a perennial herb in the Ranunculaceae family, distributes mainly in southwestern China and is commonly known as "Di Wu" in its original place [1]. Its rhizome has been used as a traditional national medicine to heal fractures for a long time [2]. Recently, a new drug extracted from its rhizomes has been developed by the Hubei University of Chinese Medicine and has shown good curative effects in the treatment of rheumatoid arthritis (RA) [3].

The habitats of $A$. flaccida plants are usually under woods in mountainous areas over $1500 \mathrm{~m}$ above sea level [4]. In natural habitats, the sprouting buds of the plant usually 
emerge in mid- to late- March from the rhizomes and then grow in spring when the weather becomes warmer. The plant enters flowering and seed production from mid- April to lateMay. In late June, its aboveground parts begin senescence and die eventually. The plant grows relatively vigorously in spring compared with that in winter; however, its growth rate is rather slow because of cool temperatures in the natural high altitude habitat. The total growth period of the species in a year is usually about 90 days. Most seeds of the plant cannot germinate probably because they often shatter before full maturity [4]; thus, the plant depends mainly on its rhizome for population propagation. The low reproductive capacity, slow growth characteristics and narrow habitat [5] have led the wild populations of the plant to be scarce and endangered due to excessive exploitation in the past years. In order to meet the requirement for medicinal usage, studies have been undertaken to grow the plant under a more controlled environment and management. For instance, Xin [6] showed that the combined application of phosphate and potassium fertilizers could promote the growth and development of the cultivated plants.

Quality control is of great importance for medicinal herb plantations. Apart from the quantification of medicinal ingredients, the expression analysis of the key genes involved in the biosynthesis of pharmacological constituents is often performed into monitor the herb quality [7]. Moreover, gene expressions can provide a deep insight to understanding how cultivation techniques and environmental factors affect the herb quality, which is conducive to developing cultivation and management methods. The main medicinal ingredients are triterpenoid saponins in the rhizome of A. flaccida [2]. In 2016, Zhan et al. [8] performed a combined transcriptomic and proteomic analysis to identify key genes in the biosynthetic pathway of triterpenoid saponins in A. flaccida, which made it possible to monitor the quality of cultivated plants through gene analysis.

Reverse transcription quantitative polymerase chain reaction (RT-qPCR), with the characteristics of high efficiency, high sensitivity and good repeatability, has been widely used to quantify the expression levels of transcripts in various organisms at various developmental stages and under different conditions $[9,10]$. In RT-qPCR analysis, the appropriate internal reference gene(s) for data normalization is an important prerequisite to ensure the accuracy. Reference genes used in RT-qPCR analysis usually play important roles in maintaining the normal life of cells and are often referred to as housekeeping genes, such as actin (ACT) [11], $18 S$ ribosomal RNA (18S rRNA) [11], Elongation Factor 1- $\alpha$ (EF1A) [12], beta tubulin ( $\beta$-tubulin) [13], glyceraldehyde-3-phosphate dehydrogenase (GAPDH) [13], pyruvate kinaseII (PKII) [14], alpha-tubulin ( $\alpha$-tubulin) [15], 28S ribosomal RNA (28SrRNA) [16], polyubiquitin (PUBQ) [17], Eukaryotic translation initiation Factor 1A (ETIF1a) [18], ubiquitin [18] and histone H2A (hh2a) [19]. Most of these genes usually express stably in different organs and at various developmental stages. However, a few of these housekeeping genes have been shown to express variably across species and tissues or under diverse conditions [12]. Failure to use suitable reference gene(s) may deviate from the gene expression profile and lead to misinterpretation [20]. Therefore, the suitable reference genes specific to the species, organs and growth conditions should be validated.

The best reference genes are usually identified by Excel-based software statistical algorithms such as geNorm [21], NormFinder [22] and BestKeeper [23]. Such identifications have been done in model plants, grain crops and a few other commercial crops such as Arabidopsis [24], rice (Oryza sativa L.) [25] and Zanthoxylum bungeanum Maxim [26]. However, in medicinal plants, similar studies have only been performed in a few major species, such as Anoectochilus roxburghii [13], Panax ginseng [27] and Tripterygium wilfordii [28]. In this study, the expression stability of 10 commonly used reference genes that were selected from a comprehensive literature search [12-19] and based on the transcriptomic data [8] was evaluated in different organs at various developmental stages of $A$. flaccida. The purpose of this study was to identify the appropriate reference gene(s) for the normalization of gene expression studies in the medicinal quality of cultivated plants in A. flaccida. 


\section{Materials and Methods}

A field experiment was conducted at the Chinese herbal medicine plantation base $\left(30^{\circ} 8^{\prime} 31^{\prime \prime}\right.$ N, $108^{\circ} 55^{\prime} 35^{\prime \prime}$ E, $1600 \mathrm{~m}$ above sea level) in Lichuan City, Hubei Province, China. Cutting rhizomes with a length of 2-3 cm were planted about $5 \mathrm{~cm}$ deep into the soil with a row spacing of $25 \mathrm{~cm}$ and plant distance of $12.5 \mathrm{~cm}$ on 26 September 2014 . The density of the rhizome plantation was 320,000 plants $/ \mathrm{hm}^{2}$. Prior to the planting of the rhizomes, $337.5 \mathrm{~kg} / \mathrm{hm}^{2}$ of urea, $1000 \mathrm{~kg} / \mathrm{hm}^{2}$ of calcium superphosphate and $625.5 \mathrm{~kg} / \mathrm{hm}^{2}$ of potassium magnesium sulphate were applied into the soil as a basal fertilizer [6]. The cultivated plants were shaded by one layer of sunshade net with $10.4 \%$ of light transmittance to imitate the natural habitat of the plant. No irrigation and herbicides were applied during the entire growing period.

The statistical analysis of the expression stability was performed for all of the tested samples (total) and separately for each growth stage for the rhizome samples and for the samples of leaves of cultivated and wild plants. Rhizomes and leaves were sampled at the vegetative stage on 3 April and flowering stage on 10 May 2015, respectively (CVR and CVL: rhizomes and leaves of the cultivated plants, respectively, at the vegetative stage; CFR and CFL: rhizomes and leaves of the cultivated plants, respectively, at the flowering stage), Rhizomes were collected from withering plants on 11 July 2015 (CWR: rhizomes of the cultivated plants at the withering stage). Leaf and rhizome samples of $A$. flaccida were also collected from wild plants at Tonggubao $\left(30^{\circ} 17^{\prime} 22^{\prime \prime} \mathrm{N}, 110^{\circ} 49^{\prime} 11^{\prime \prime} \mathrm{E}, 1800 \mathrm{~m}\right.$ above sea level), a natural habitat of the plant, in Changyang county, Hubei Province, China on 6 April, 13 May and 14 July 2015, respectively (WVR and WVL: rhizomes and leaves of the wild plants, respectively, at the vegetative stage; WFR and WFL: rhizomes and leaves of the wild plants, respectively, at the flowering stage; WWR: rhizomes of the wild plants at withering stage). Following thorough cleaning by tap water, the samples were immediately put into liquid nitrogen and brought to the laboratory for analysis. All samples were collected in three biological replicates.

\subsection{Total RNA Isolation and Quality Control}

Frozen samples ( $2 \mathrm{~g}$ of leaves and $1 \mathrm{~g}$ of rhizomes) were ground with a pre-cooled mortar and pestle in liquid nitrogen. Total RNA was extracted from the leaves and rhizomes by Trizol Reagent (Invitrogen, Carlsbad, CA, USA) following the manufacturer's instructions on a Heraguard ECO Clean Bench (Thermo Fisher Scientific, Waltham, MC, USA). The quality and quantity of RNA were checked by agarose gel electrophoresis and spectrophotometry (NanoDrop Technologies, Wilmington, DE, USA). RNA samples with A260/A280 between 1.8-2.2 were used for further RT-qPCR analysis.

\subsection{Candidate Reference Gene Selections}

Based on the transcriptome data sequences of A. flaccida [8], the potential homologues of 10 commonly used housekeeping genes were selected as candidate reference genes in this study: EF1A [12], $\beta$-tubulin [13], GAPDH [13], PKII [14], $\alpha$-tubulin [15], 28SrRNA [16], PUBQ [17], ETIF1a [18], ubiquitin [18] and hh2a [19].

\subsection{Primer Design and Amplification Efficiency Test}

Primers for the amplification of candidate reference genes were designed using Oligo7.0 software (V7.56 version) based on the data of Zhan et al. [8] with an annealing temperature between $58{ }^{\circ} \mathrm{C}$ and $62^{\circ} \mathrm{C}$, a primer length of 20-24 bp, GC content about $45 \%-55 \%$ and an amplicon length of 126-156 bp (Table 1, Figures S1 and S2). For each pair of primers, a standard curve was generated using five different cDNA concentrations $\left(1,5^{-1}, 5^{-2}, 5^{-3}\right.$ and $5^{-4}$ fold dilutions with three replicates, respectively) (Figure S3). The cycle threshold $(\mathrm{Ct})$ values were automatically determined for each reaction using CFX-1000 PCR apparatus (Analytik Jena AG company, Berlin, Germany). The amplification efficiency (E) for each gene was determined with the slope of a linear regression model [12] using the $\mathrm{Ct}$ values and the following equation: $\mathrm{E}=10^{-1 / \text { slpoe }}$. 
Table 1. Primer information and amplification efficiency of 10 candidate reference genes.

\begin{tabular}{|c|c|c|c|c|c|c|}
\hline Gene & Gene Name & Primer Sequence $\left(5^{\prime}-3^{\prime}\right)$ & $\begin{array}{c}\text { Amplicon } \\
\text { Length } \\
\text { (bp) }\end{array}$ & $\underset{\left({ }^{\circ} \mathrm{C}\right)}{\mathrm{Tm}}$ & $\begin{array}{l}\text { Determination } \\
\text { Coefficient }\left(\mathbf{R}^{2}\right)\end{array}$ & E \\
\hline$\beta$-tubulin & Beta-tubulin & $\begin{array}{l}\text { F: GCCTGCTTGAATGTGGAGAATCT } \\
\text { R: CCCTTCACAAATCGCAATCTCAAC }\end{array}$ & 129 & $\begin{array}{l}57.8 \\
57.9\end{array}$ & 0.980 & 1.84 \\
\hline$P U B Q$ & Polyubiquitin & $\begin{array}{l}\text { F: CAAGTGACACCAATGCCCTAAACT } \\
\text { R: GATGGCAGGGTATATTTTCCTACGC }\end{array}$ & 151 & $\begin{array}{l}57.9 \\
59.6\end{array}$ & 0.975 & 1.86 \\
\hline ETIF1a & $\begin{array}{l}\text { Eukaryotic translation } \\
\text { initation factor } 1 \mathrm{~A}\end{array}$ & $\begin{array}{c}\text { F: TGTTCTTCGGCATGGCTACT } \\
\text { R: CCACGGCTCTCGTTCATCTAA }\end{array}$ & 126 & $\begin{array}{l}55.4 \\
57.6\end{array}$ & 0.981 & 2.00 \\
\hline ubiquitin & Ubiquitin & $\begin{array}{l}\text { F: CTCATCACCAGCACCTACATC } \\
\text { R: CCGATTCCGCAACCAAGT }\end{array}$ & 146 & $\begin{array}{l}54.9 \\
54.9\end{array}$ & 0.992 & 2.01 \\
\hline PKII & Pyruvate kinase II & $\begin{array}{l}\text { F: GATGATGCTGCGGCTTGAAG } \\
\text { R: CCAACAGACGGATTGGATTATCTC }\end{array}$ & 137 & $\begin{array}{l}57.4 \\
57.9\end{array}$ & 0.983 & 2.08 \\
\hline GAPDH & $\begin{array}{l}\text { Glyceraldehyde-3- } \\
\text { phosphate dehydrogenase }\end{array}$ & $\begin{array}{c}\text { F: CCGAGTCCTGGATCTGATT } \\
\text { R: GGGTGCAAACTAGATAACTGG }\end{array}$ & 124 & $\begin{array}{l}55.6 \\
55.2\end{array}$ & 0.997 & 2.13 \\
\hline$\alpha$-tubulin & Alpha-tubulin & $\begin{array}{l}\text { F: ACATGCGATGTAATGGCAAGAAGC } \\
\text { R: GGTGCTTGTTCTGTTCTCCAGTGA }\end{array}$ & 134 & $\begin{array}{l}57.9 \\
59.6\end{array}$ & 0.963 & 1.81 \\
\hline EF1A & Elongation Factor $1-\alpha$ & $\begin{array}{c}\text { F: AGGCGGAGAGGCTTATCA } \\
\text { R: GAGGTCTACTAATCTGGACTGGTA }\end{array}$ & 147 & $\begin{array}{l}54.9 \\
57.9\end{array}$ & 0.984 & 1.92 \\
\hline$h h 2 a$ & Histone $\mathrm{H} 2 \mathrm{~A}$ & $\begin{array}{l}\text { F: TCAGCTTCAGCTCAAGCACTAACATCAG } \\
\text { R: GGCGTTCCTGTGGTGTAGTTGTATGG }\end{array}$ & 145 & $\begin{array}{l}61.1 \\
62.7\end{array}$ & 0.905 & 2.00 \\
\hline $28 S r R N A$ & $28 \mathrm{~S}$ ribosomal RNA & $\begin{array}{l}\text { F: TCTAGTAACGGCGAGTGAAG } \\
\text { R: GGAACTTAGGTCGGTGGTTA }\end{array}$ & 156 & $\begin{array}{l}55.4 \\
55.4\end{array}$ & 0.984 & 1.94 \\
\hline
\end{tabular}

E, Amplification efficiency for each gene.

\subsection{Reverse Transcription Quantitative Polymerase Chain Reaction (RT-qPCR)}

The first strand cDNA was synthesized with $1 \mu \mathrm{g}$ of high-quality total RNA and $1 \mu \mathrm{L}$ of oligo dT primers ( $50 \mu \mathrm{mol} / \mathrm{L})$ for each sample according to the Thermo RevertAid First Strand cDNA Synthesis Kit (Thermo Fisher Scientific, USA). The RT-qPCR assays were carried out with a CFX-1000 PCR apparatus and SYBR Premix Ex TaqII (Wuhan Khayal Bio-Technology Company, Wuhan, China) to test the transcription variability of the 10 candidate reference genes across the samples. The total reaction volume was $20 \mu \mathrm{L}$, containing $1 \mu \mathrm{L}$ of diluted cDNA, $10 \mu \mathrm{L}$ of $2 \times$ Ultra SYBR Mixture, $0.4 \mu \mathrm{L}$ of each primer $(10 \mu \mathrm{mol} / \mathrm{L})$ and $8.2 \mu \mathrm{L}$ of RNase-free water. The three steps of RT-qPCR program began with $95^{\circ} \mathrm{C}$ for $10 \mathrm{~min}, 45$ cycles of $95^{\circ} \mathrm{C}$ for $15 \mathrm{~s}$ and $60^{\circ} \mathrm{C}$ for $15 \mathrm{~s}$, followed by $72^{\circ} \mathrm{C}$ for $10 \mathrm{~min}$. The dissociation curve was obtained by heating the amplicon from $56^{\circ} \mathrm{C}$ to $95^{\circ} \mathrm{C}$. Each RT-qPCR reaction was carried out with three technical replicates and a template-free control.

\subsection{Statistical Analysis on Gene Expression Stability}

The expression stability of the 10 candidate genes was evaluated by $\mathrm{Ct}$ value [29] and three different algorithms: geNorm (http:/ / medgen.ugent.be/jvdesomp/genorm/, accessed on 20 July 2018), NormFinder (http:/ / www.mdl.dk/publicationsnormfinder.html, accessed on 20 July 2018) and BestKeeper (http:/ /www.genequantification.de/bestkeeper.html, accessed on 20 July 2018). The geNorm algorithm calculates the expression stability (defined as the parameter M) of each candidate reference gene based on its expression level in a set of given samples. The gene with the lower $\mathrm{M}$ value indicates a higher expression stability $[15,21]$. The geNorm algorithm selects the optimal number of required reference genes by comparing the pair-wise variation $(\mathrm{Vn} / \mathrm{Vn}+1)$ values between consecutively ranked genes. The cut-off values are usually recommended to be a default value of 0.15 [21,30]. Similarto the geNorm algorithm, the NormFinder algorithm uses a model-based approach to determine the expression stability of reference genes based on intra- and inter- group variations. Herein, the gene with the lowest mean expression stability value is considered to be the most stably expressed [23,31]. BestKeeper evaluates and ranks the expression stability of candidate reference genes by calculating the standard deviation (SD) and the coefficient of variation $(\mathrm{CV})$ based on the $\mathrm{Ct}$ values. The most stably expressed reference gene presents the lowest standard deviation $(\mathrm{CV} \pm \mathrm{SD})[24,32]$. Following RT-qPCR data collection, amplification cycles (Ct values) were converted to relative quantities using the equation $E^{-\Delta \mathrm{Ct}}(\Delta \mathrm{Ct}=$ the corresponding $\mathrm{Ct}$ value - minimum $\mathrm{Ct}$ ). The relative quantities were then used for 
the gene expression stability evaluation by geNorm, NormFinder and BestKeeper analyses, respectively, according to the manufacturer's instructions.

\section{Results}

\subsection{Validating Expression Levels of Candidate Reference Genes}

The specificity of the primers used for the candidate reference genes were verified by reverse transcription PCR. There were no primer dimers and nonspecific amplification as checked by agarose gel electrophoresis (Figure S1). There were great variations in the transcript levels of the 10 candidate reference genes in the different samples of $A$. flaccida (Figure 1). The mean $\mathrm{Ct}$ values of the genes ranged from 22.82 to 28.06 across all samples. Among them, PKII had the lowest mean $\mathrm{Ct}$ value and $\beta$-tubulin had the highest mean $\mathrm{Ct}$ indicating the highest expression level for PKII but the lowest for $\beta$-tubulin. The expression level of $P U B Q$ presented the least variation $(C V=0.2 \%)$, while that of $G A P D H$ presented the most variation $(\mathrm{CV}=5.78 \%)$ across all samples (Figure 1$)$.

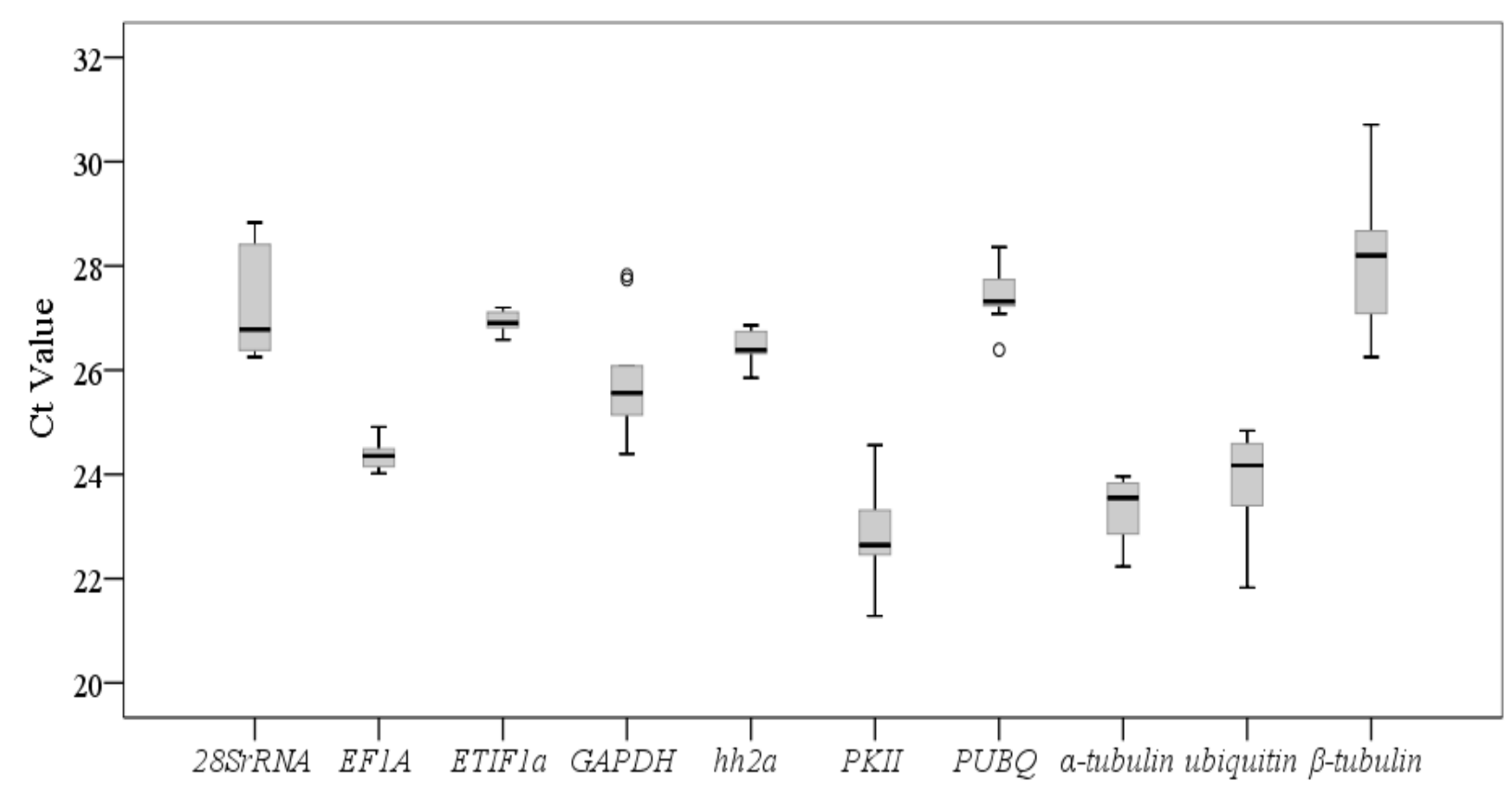

Figure 1. Expression levels of 10 candidate reference genes in different samples. Lines across the boxes depict the medians. Boxes indicate the interquartile range. Whiskers represent $95 \%$ confidence intervals and black circles represent the deviated values.

The relative quantitative expression of each gene in different organs at various stages is presented as the percentage of the aggregated reference transcript pool in Figure 2. The proportions of EF1A,PUBQ, ETIF1a and $\beta$-tubulin transcripts were relatively consistent while, those of $\alpha$-tubulin, 28S rRNA, PKII, hh2a, GAPDH and ubiquitin transcripts were more variable across the samples. The proportions of the gene transcripts were comparable in the same organs between wild and cultivated plants at the same stage, except for those of PKII and 28S rRNA in the rhizomes at the vegetative stage, ubiquitin and GAPDH in the leaves at the vegetative stage, GAPDH, PKII, hh2a and $\alpha$-tubulin in the rhizomes and leaves at the flowering stage, ubiquitin in the leaves at the flowering stages and PKII and $h h 2 a$ in the rhizomes at the withering stage (Figure 2). 


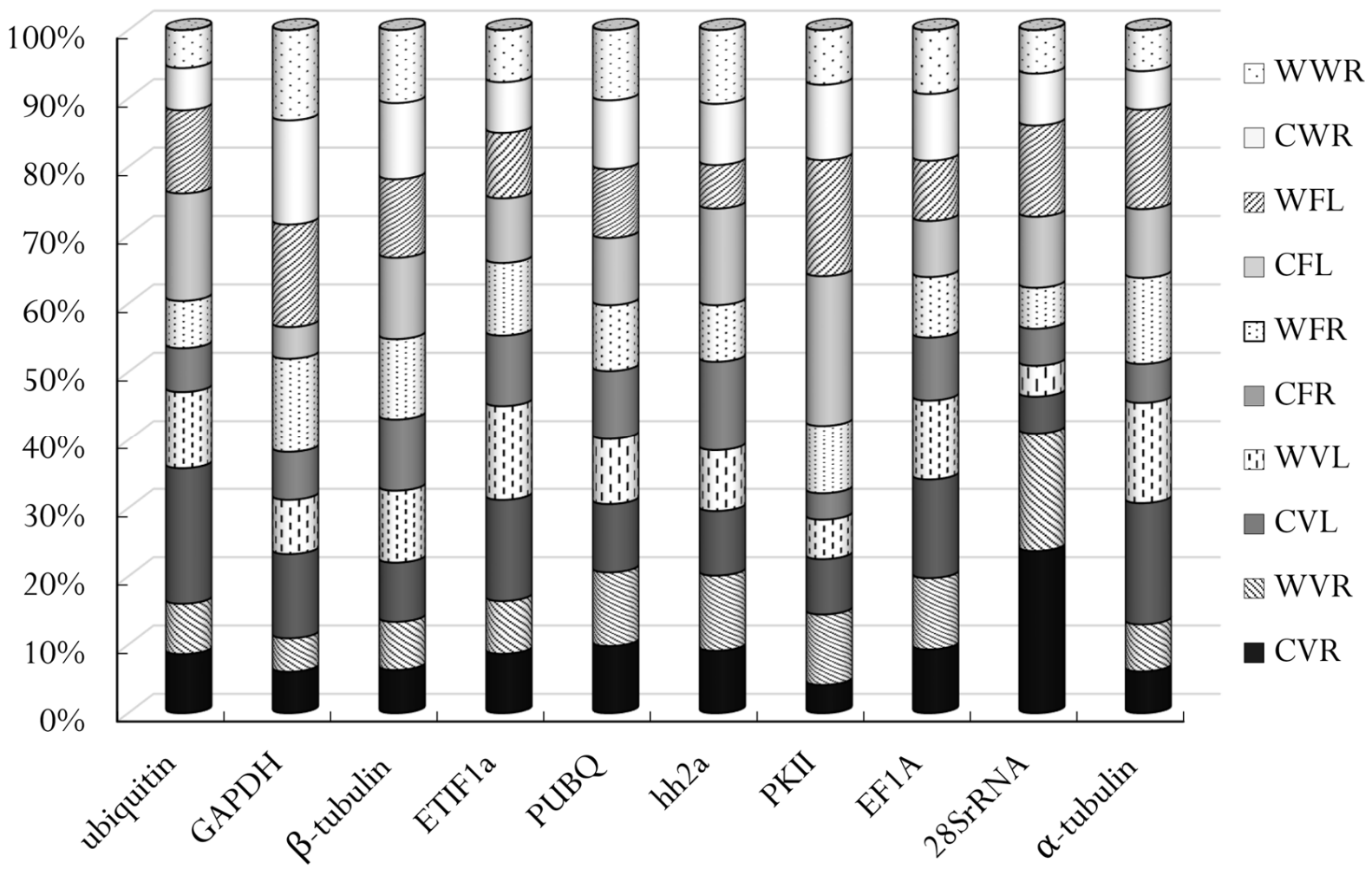

Figure 2. Relative expression levels of 10 candidate reference genes in different samples. CVR: rhizomes of the cultivated plants at the vegetative stage; WVR: rhizomes of the wild plants at the vegetative stage; CVL: leaves of the cultivated plants at the vegetative stage; WVL: leaves of the wild plants at the vegetative stage; CFR: rhizomes of the cultivated plants at the flowering stage; WFR: rhizomes of the wild plants at the flowering stage; CFL: leaves of the cultivated plants at the flowering stage; WFL: leaves of the wild plants at the flowering stage; CWR: rhizomes of the cultivated plants at the withering stage; WWR: rhizomes of the wild plants at the withering stage.

\subsection{Expression Stability of Candidate Reference Genes}

\subsection{1. geNorm Analysis}

The tested reference genes by geNorm showed relatively stable expressions with $\mathrm{M}$ values less than 1.5 (Figure 3). The expressions of $P U B Q$ and $E F 1 A$ were the most stable while those of $28 S r R N A$ and PKII were the least stable across all samples (Figure 3a). At the vegetative stage, $P U B Q$ and $E F 1 A$ also kept the most stable expression in the rhizomes as well as PUBQ and $h h 2 a$ in the leaves while PKII and $28 S r R N A$ showed the least stable expression in the rhizomes and $\beta$-tubulin and ubiquitin in the leaves (Figure $3 \mathrm{~b}, \mathrm{c}$ ). At the flowering stage, the expressions of ETIF1 $a$ and EF1A were the most stable in the rhizomes as well as those of ETIF1 $a$ and PUBQ in the leaves (Figure 3d,e). The least stably expressed genes were PKII in the rhizomes and GAPDH in the leaves at the flowering stage. At the withering stage, ETIF1 $a$ and EF1A were the most stably expressed genes but PKII was the least stably expressed gene in the rhizomes (Figure 3f). Most V3/4 values (VR: 0.005; VL: 0.033; FR: 0.017; FL: 0.019) were larger than the V2/3 values (VR: 0.003; VL: 0.007; FR: 0.01; FL: 0.018 ) and all the of V2/3 values were below 0.15 (Figure 4). This indicated that two reference genes could be sufficient for normalizing gene expressions in A. flaccida samples. The addition of a third reference gene did not significantly increase the statistical reliability of the calculation. 


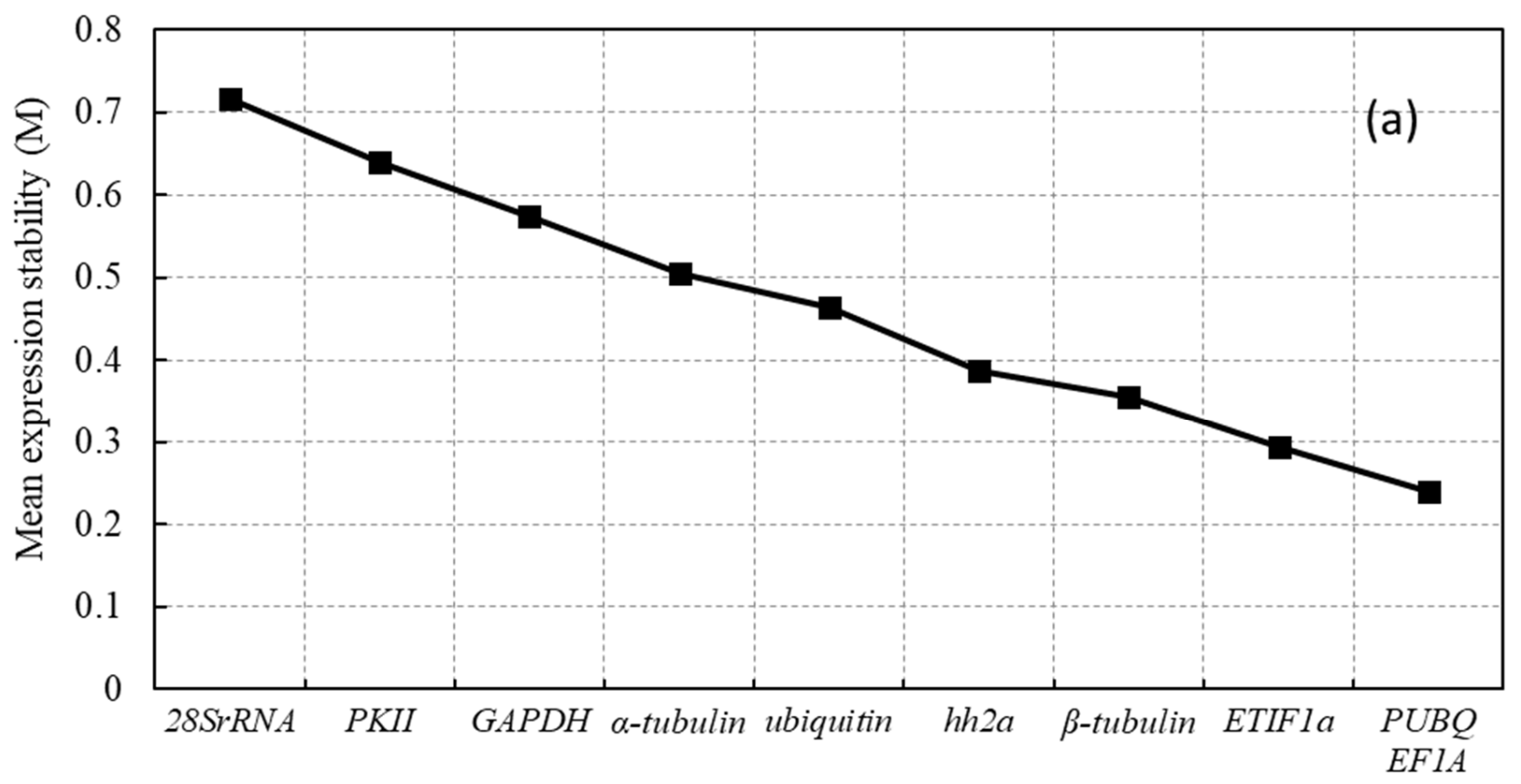

$<\cdots:$ Least stable genes $\quad$ Most stable genes :..: $>$

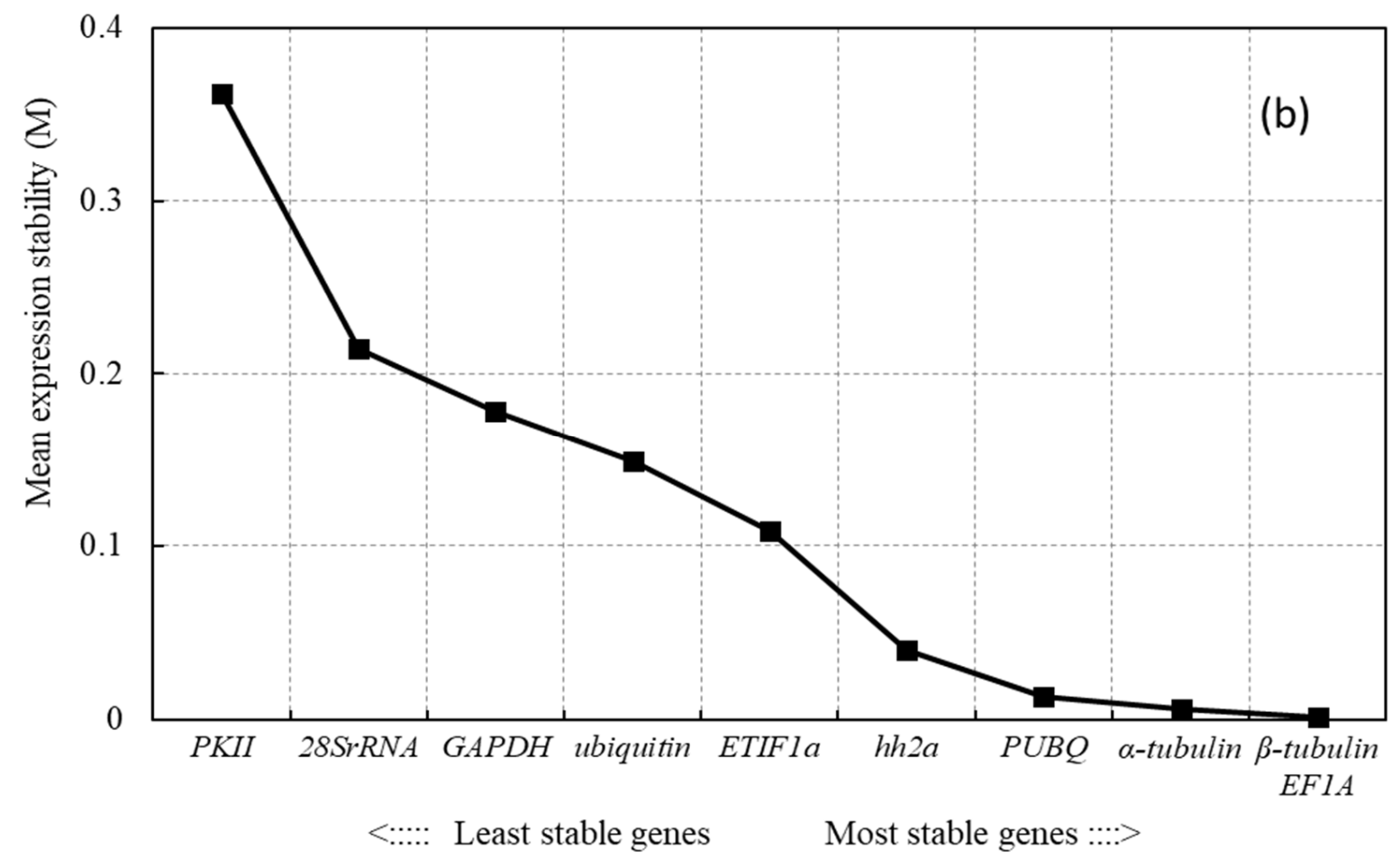

Figure 3. Cont. 


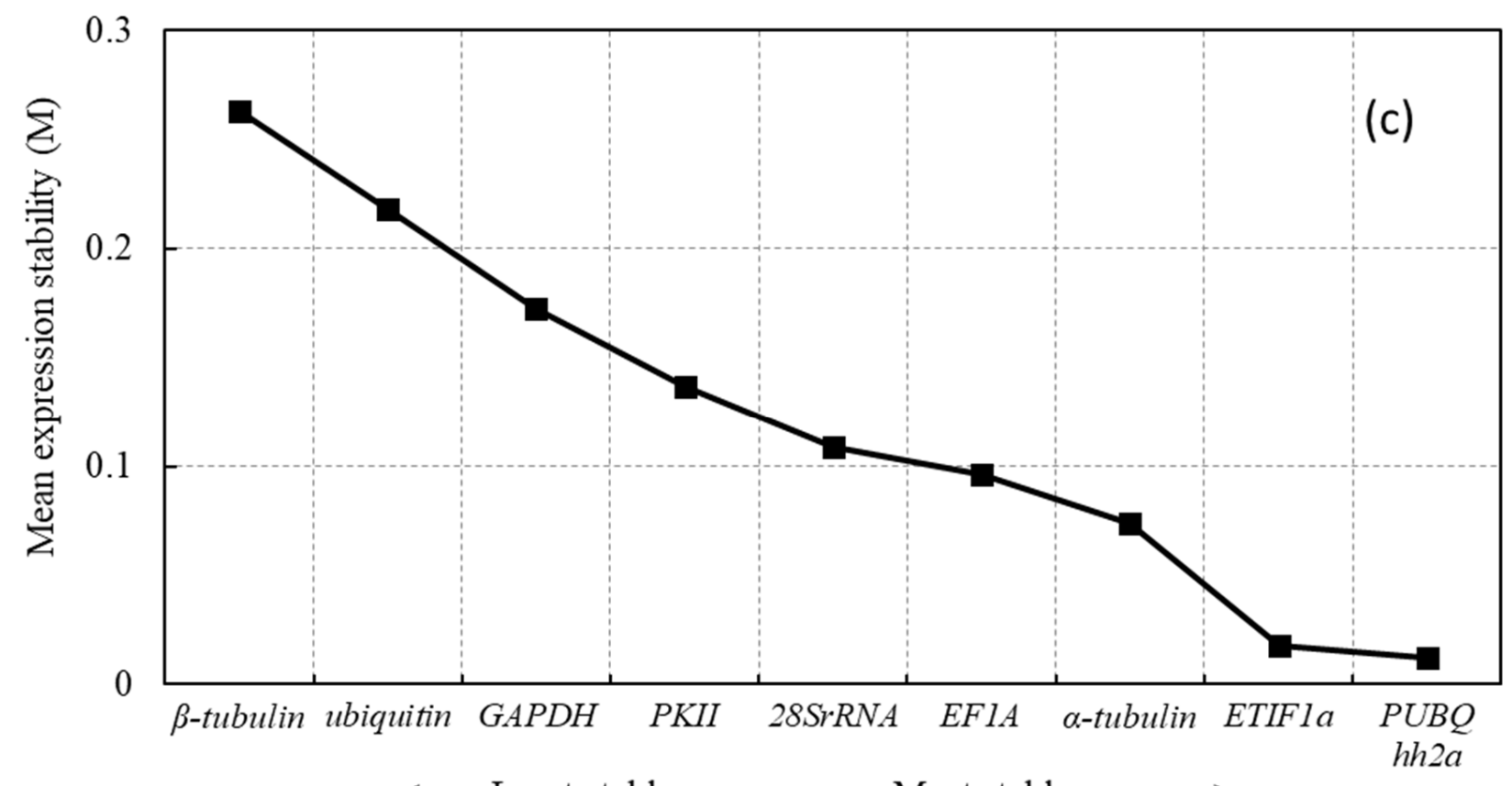

$<\ldots . . .:$ Least stable genes $\quad$ Most stable genes :...: $>$

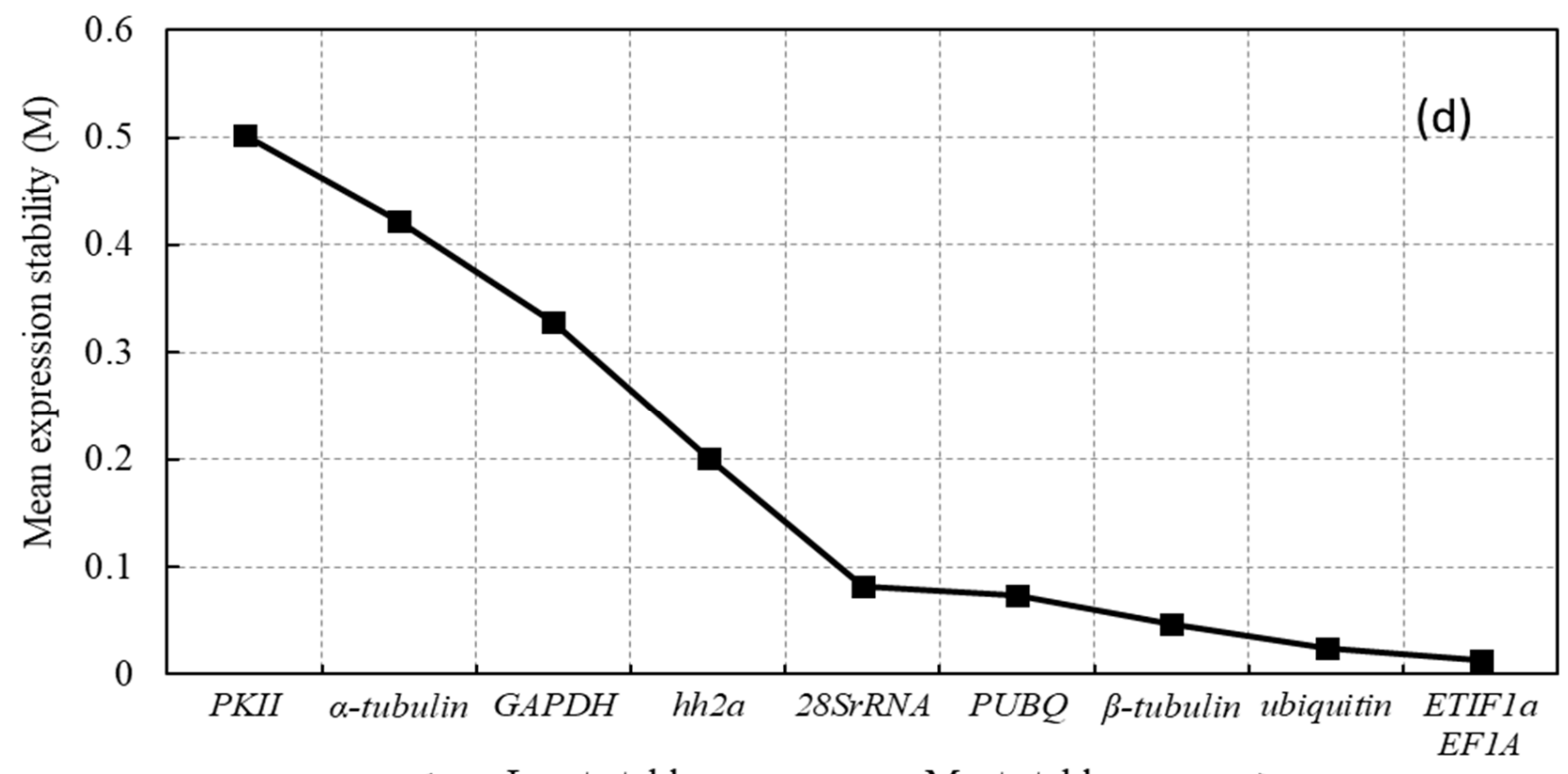

$<\cdots:$ Least stable genes $\quad$ Most stable genes :...: $>$

Figure 3. Cont. 

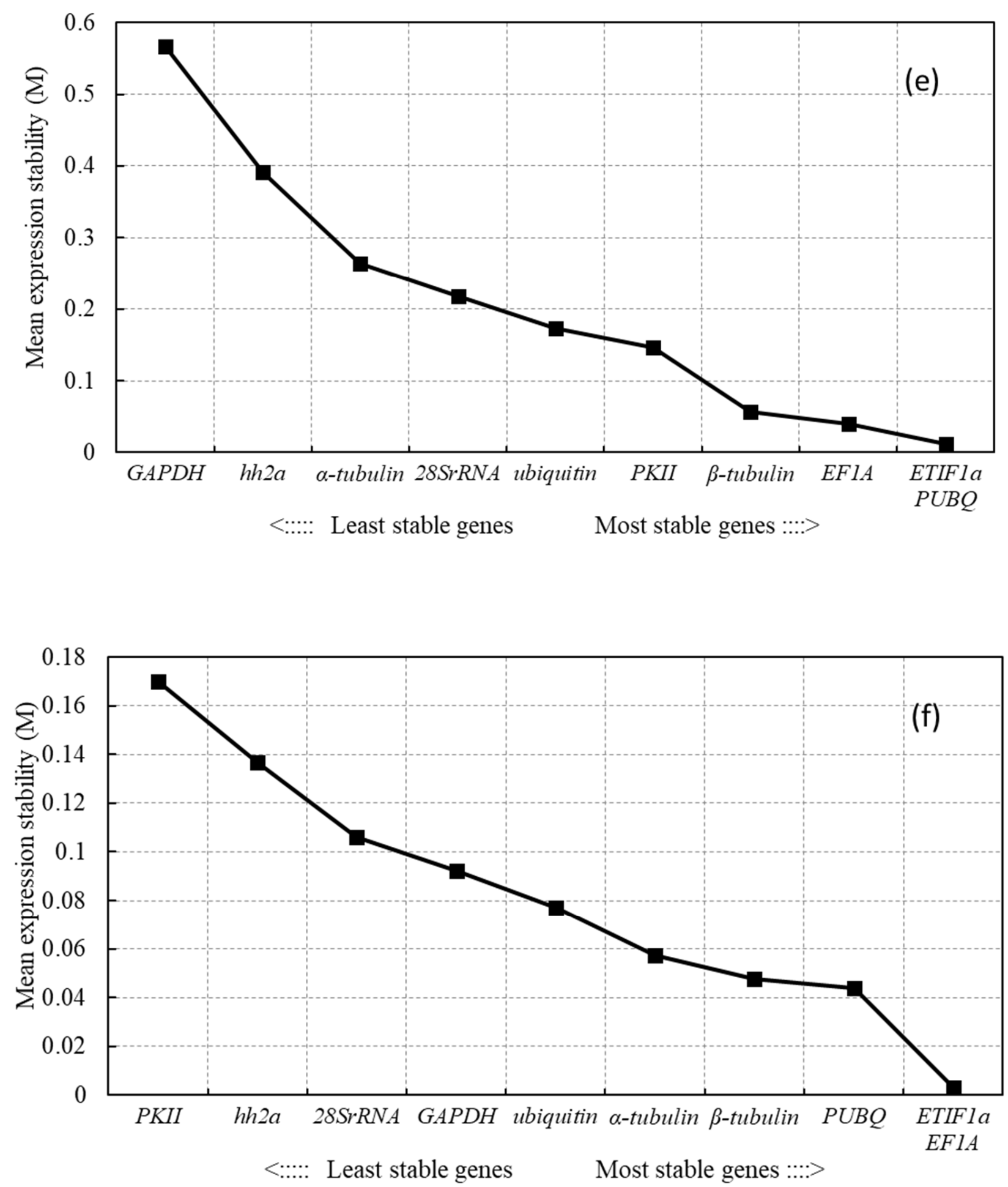

Figure 3. Expression stability and ranking of 10 candidate reference genes calculated by geNorm. The mean expression stability was calculated by a stepwise exclusion of the least stable gene across all samples. The least stable genes are on the leftand the most stable ones on the right. The statistical analysis of the expression stability was performed for all of the tested samples (Total) and separately for each growth stage for the rhizome samples and for the samples of the leaves of the cultivated and wild plants. (a) Total: all rhizome and leaf samples of cultivated and wild plants; (b) VR: rhizomes at the vegetative stage; (c) VL: leaves at the vegetative stage; (d) FR: rhizomes at the flowering stage; (e) FL: leaves at the flowering stage; (f) WR: rhizomes at the withering stage. 


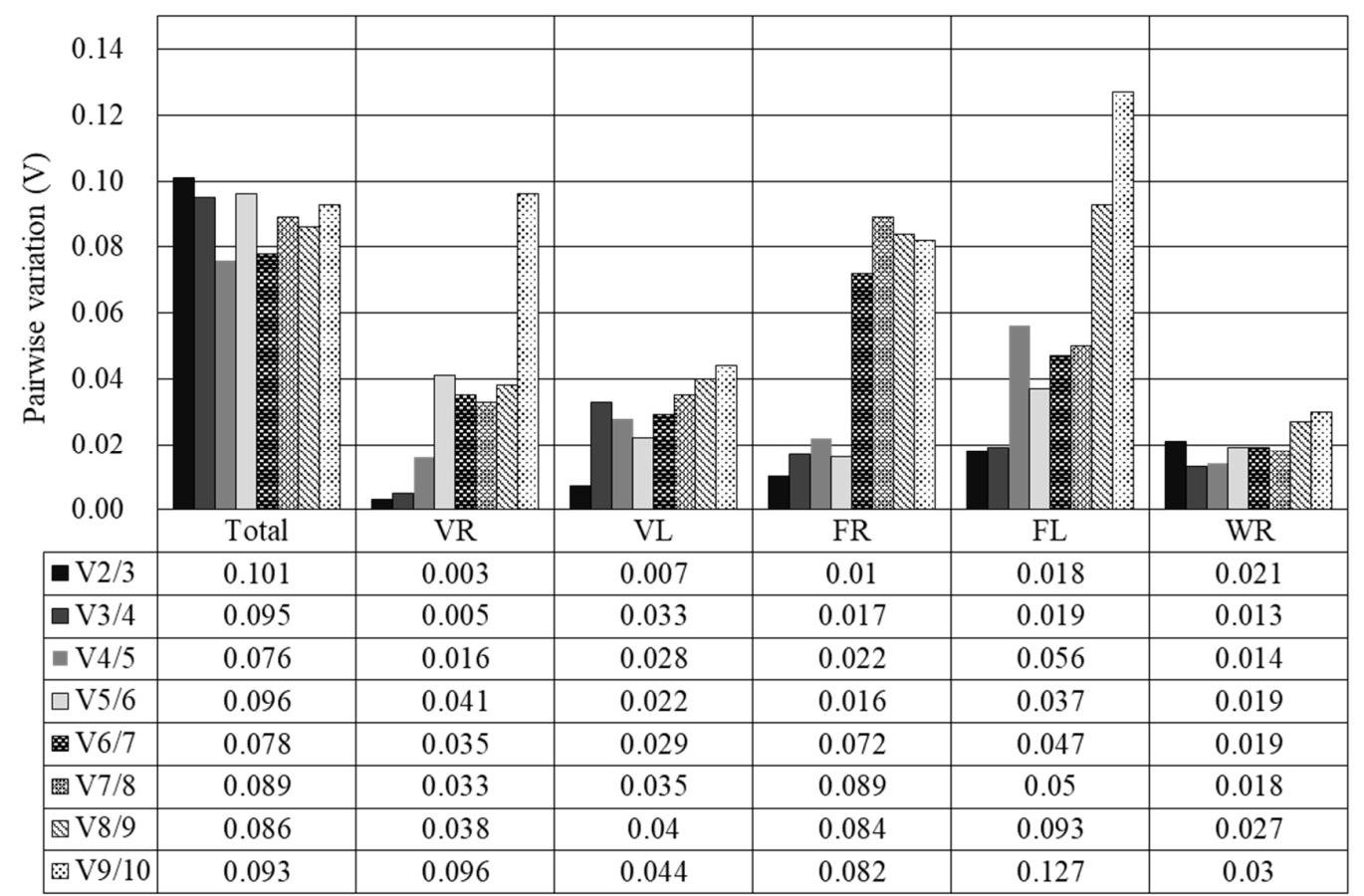

Figure 4. Determination of the optimal number of reference genes required for effective normalization. A pairwise variation $(\mathrm{Vn} / \mathrm{Vn}+1)$ analysis between the normalization factors (NFn and NFn+1) was performed by the geNorm program to determine the optimal number of reference genes that might be carried out for RT-qPCR data normalization in various sample pools. The statistical analysis of the expression stability was performed for all of the tested samples (Total) and separately for each growth stage for the rhizome samples and for the samples of the leaves of the cultivated and wild plants. Total: all rhizome and leaf samples of the cultivated and wild plants; VR: rhizomes at the vegetative stage; VL: leaves at the vegetative stage; FR: rhizomes at the flowering stage; FL: leaves at the flowering stage; WR: rhizomes at the withering stage.

\subsubsection{NormFinder Analysis}

The expression stability of 10 candidate reference genes resulted from NormFinder analysis demonstrated that $P U B Q$ was the most stably expressed gene in all samplesexcept for the rhizomes at the vegetative and withering stages in which EF1A was ranked as the most stably expressed gene (Table 2).

Table 2. Expression stability of the candidate reference genes calculated by the NormFinder software.

\begin{tabular}{|c|c|c|c|c|c|c|c|c|c|c|c|c|}
\hline \multirow{2}{*}{ Rank } & \multicolumn{2}{|c|}{ Total } & \multicolumn{2}{|c|}{ VR } & \multicolumn{2}{|c|}{ VL } & \multicolumn{2}{|c|}{ FR } & \multicolumn{2}{|c|}{ FL } & \multicolumn{2}{|c|}{ WR } \\
\hline & Gene & Stability & Gene & Stability & Gene & Stability & Gene & Stability & Gene & Stability & Gene & Stability \\
\hline 1 & $P U B Q$ & 0.094 & EF1A & 0.002 & $P U B Q$ & 0.002 & $P U B Q$ & 0.004 & $P U B Q$ & 0.004 & $E F 1 A$ & 0.001 \\
\hline 2 & $E F 1 A$ & 0.167 & $P U B Q$ & 0.003 & ETIF1a & 0.002 & ETIF1a & 0.004 & $E F 1 A$ & 0.004 & $\beta$-tubulin & 0.001 \\
\hline 3 & ETIF1a & 0.206 & $\alpha$-tubulin & 0.004 & EF1A & 0.011 & ubiquitin & 0.031 & ETIF1a & 0.017 & ubiquitin & 0.026 \\
\hline 4 & $\beta$-tubulin & 0.210 & ETIF1a & 0.006 & $\alpha$-tubulin & 0.078 & $h h 2 a$ & 0.106 & $\beta$-tubulin & 0.018 & $P U B Q$ & 0.046 \\
\hline 5 & $h h 2 a$ & 0.316 & $h h 2 a$ & 0.029 & $h h 2 a$ & 0.091 & PKII & 0.166 & $28 S r R N A$ & 0.086 & ETIF1a & 0.055 \\
\hline 6 & ubiquitin & 0.344 & $\beta$-tubulin & 0.124 & 28SrRNA & 0.102 & $E F 1 A$ & 0.173 & $\alpha$-tubulin & 0.211 & GAPDH & 0.060 \\
\hline 7 & $\alpha$-tubulin & 0.372 & ubiquitin & 0.162 & PKII & 0.103 & GAPDH & 0.335 & PKII & 0.212 & $\alpha$-tubulin & 0.083 \\
\hline 8 & GAPDH & 0.494 & GAPDH & 0.208 & GAPDH & 0.189 & $\alpha$-tubulin & 0.441 & ubiquitin & 0.212 & 28SrRNA & 0.091 \\
\hline 9 & PKII & 0.506 & 28SrRNA & 0.297 & ubiquitin & 0.295 & $\beta$-tubulin & 0.519 & $h h 2 a$ & 0.662 & $h h 2 a$ & 0.188 \\
\hline 10 & $28 S r R N A$ & 0.635 & PKII & 0.661 & $\beta$-tubulin & 0.299 & $28 S r R N A$ & 0.562 & GAPDH & 0.877 & PKII & 0.208 \\
\hline
\end{tabular}

The statistical analysis of the expression stability was performed for all of the tested samples (Total) and separately for each growth stage for the rhizome samples and for the samples of the leaves of the cultivated and wild plants. Total: all rhizome and leaf samples of cultivated and wild plants; VR: rhizomes at the vegetative stage; VL: leaves at the vegetative stage; FR: rhizomes at the flowering stage; FL: leaves at the flowering stage; WR: rhizomes at the withering stage. 


\subsubsection{BestKeeper Analysis}

The results obtained by the BestKeeper analysis showed that all of the SD values of Ct of the 10 candidate reference genes were smaller than 1 , and the expression of $P U B Q$ was the most stable in total samples and in the rhizomes and leaves at the vegetative stage while ETIF1a was ranked as the most stable gene in the other samples (Table 3).

Table 3. Expression stability of the candidate reference genes calculated by the BestKeeper software.

\begin{tabular}{|c|c|c|c|c|c|c|}
\hline Rank & Total & VR & VL & FR & FL & WR \\
\hline 1 & $P U B Q$ & $P U B Q$ & $P U B Q$ & ETIF1a & ETIF1a & ETIF1a \\
\hline $\mathrm{CV} \pm \mathrm{SD}$ & $0.14 \pm 0.04$ & $0.27 \pm 0.07$ & $0.13 \pm 0.04$ & $0.07 \pm 0.02$ & $0.04 \pm 0.01$ & $0.05 \pm 0.02$ \\
\hline 2 & EF1A & EF1A & $h h 2 a$ & $P U B Q$ & $P U B Q$ & $P U B Q$ \\
\hline $\mathrm{CV} \pm \mathrm{SD}$ & $0.76 \pm 0.18$ & $0.35 \pm 0.08$ & $0.15 \pm 0.04$ & $0.10 \pm 0.03$ & $0.07 \pm 0.02$ & $0.07 \pm 0.02$ \\
\hline 3 & $h h 2 a$ & ETIF1a & ETIF1a & EF1A & $\beta$-tubulin & EF1A \\
\hline $\mathrm{CV} \pm \mathrm{SD}$ & $0.96 \pm 0.25$ & $0.31 \pm 0.09$ & $0.19 \pm 0.05$ & $0.12 \pm 0.03$ & $0.11 \pm 0.03$ & $0.14 \pm 0.03$ \\
\hline 4 & ETIF1a & $\beta$-tubulin & $28 S r R N A$ & ubiquitin & $E F 1 A$ & $\beta$-tubulin \\
\hline $\mathrm{CV} \pm \mathrm{SD}$ & $0.98 \pm 0.26$ & $0.31 \pm 0.09$ & $0.47 \pm 0.14$ & $0.22 \pm 0.06$ & $0.22 \pm 0.06$ & $0.12 \pm 0.04$ \\
\hline 5 & $\beta$-tubulin & $\alpha$-tubulin & $\alpha$-tubulin & $28 \operatorname{SrRNA}$ & PKII & $\alpha$-tubulin \\
\hline $\mathrm{CV} \pm \mathrm{SD}$ & $1.02 \pm 0.29$ & $0.42 \pm 0.10$ & $0.70 \pm 0.15$ & $0.26 \pm 0.07$ & $0.78 \pm 0.17$ & $0.21 \pm 0.05$ \\
\hline 6 & ubiquitin & ubiquitin & $\beta$-tubulin & $\beta$-tubulin & ubiquitin & ubiquitin \\
\hline $\mathrm{CV} \pm \mathrm{SD}$ & $2.15 \pm 0.52$ & $0.47 \pm 0.11$ & $0.56 \pm 0.16$ & $0.32 \pm 0.09$ & $0.79 \pm 0.19$ & $0.32 \pm 0.08$ \\
\hline 7 & GAPDH & $h h 2 a$ & EF1A & $h h 2 a$ & $28 S r R N A$ & GAPDH \\
\hline $\mathrm{CV} \pm \mathrm{SD}$ & $2.14 \pm 0.55$ & $0.51 \pm 0.14$ & $0.70 \pm 0.16$ & $1.24 \pm 0.33$ & $0.69 \pm 0.19$ & $0.38 \pm 0.10$ \\
\hline 8 & PKII & GAPDH & PKII & GAPDH & $\alpha$-tubulin & $h h 2 a$ \\
\hline $\mathrm{CV} \pm \mathrm{SD}$ & $2.47 \pm 0.58$ & $0.53 \pm 0.14$ & $0.96 \pm 0.23$ & $1.71 \pm 0.44$ & $1.37 \pm 0.31$ & $0.51 \pm 0.14$ \\
\hline 9 & $\alpha$-tubulin & $28 S r R N A$ & GAPDH & PKII & $h h 2 a$ & 28SrRNA \\
\hline $\mathrm{CV} \pm \mathrm{SD}$ & $2.98 \pm 0.69$ & $0.91 \pm 0.24$ & $1.13 \pm 0.29$ & $2.69 \pm 0.65$ & $2.19 \pm 0.58$ & $0.48 \pm 0.14$ \\
\hline 10 & $28 S r R N A$ & PKII & ubiquitin & $\alpha$-tubulin & GAPDH & PKII \\
\hline $\mathrm{CV} \pm \mathrm{SD}$ & $2.56 \pm 0.71$ & $2.61 \pm 0.63$ & $1.75 \pm 0.41$ & $2.88 \pm 0.67$ & $2.99 \pm 0.78$ & $0.94 \pm 0.22$ \\
\hline
\end{tabular}

The statistical analysis of the expression stability was performed for all of the tested samples (total) and separately for each growth stage for the rhizome samples and for the samples of the leaves of the cultivated and wild plants. Total: all rhizome and leaf samples of cultivated and wild plants; VR: rhizomes at the vegetative stage; VL: leaves at the vegetative stage; FR: rhizomes at the flowering stage; FL: leaves at the flowering stage; WR: rhizomes at withering stage. Descriptive statistics of 10 candidate genes based on the coefficient of variance (CV) and standard deviation (SD) of their $\mathrm{Ct}$ values were determined using the whole data set. Reference genes were identified as the most stable genes with the lowest coefficient of variance and standard deviation $(\mathrm{CV} \pm \mathrm{SD})$.

\section{Discussion}

The selection of suitable reference gene(s) is crucial for obtaining reliable and reproducible results of target gene expressions in different experimental conditions by RT-qPCR analysis [30,31]. An ideal reference gene should be relatively consistent in expression across all organs and experimental conditions [27]. In this study, $P U B Q$ showed a stable expression in most cases for A. flaccida, which was in line with the previous findings in Cicer arietinum [17]. GAPDH has been recommended as a suitable reference gene in sugarcane (Saccharum sp.) [33]; however, its expression was not so stable for A. flaccida in this study. Similar results were also obtained in Miscanthus lutarioriparia [30]. These suggested that reference genes need to be verified under certain experimental conditions and among various species or organs $[28,34]$.

The results of reference gene selections using RT-qPCR are also affected by reagents and analysis software. Three analytical software platforms and high-quality reagents were used to ensure the reliability of results in this study. geNorm, NormFinder and BestKeeper 
have been widely used to analyze the stability of gene expression and identify the best reference gene(s) for data normalization in RT-qPCR studies. In this study, $P U B Q$ was ranked as the most stably expressed gene in all of the tested samples by the three methods. However, EF1A was ranked as the first and $P U B Q$ as the second most stable gene in the rhizomes at the vegetative stage by The NormFinder. NormFinder algorithm uses a modelbased approach to determine the expression stability of reference genes based on intra- and inter- group variation. BestKeeper evaluates and ranks the expression stability of candidate reference genes by calculating the standard deviation (SD) and the coefficient of variation $(\mathrm{CV})$ based on the $\mathrm{Ct}$ values. The most stably expressed reference gene presents the lowest standard deviation $(\mathrm{CV} \pm \mathrm{SD})$ [23]. By BestKeeper, ETIF1 $a$ was ranked as the first most stable gene and $P U B Q$ the second in different organs at the flowering and withering stages in this study although the $P U B Q$ expression was the most stable at the vegetative stage.

The geNorm algorithm calculates the expression stability (defined as the parameter M) of each candidate reference gene based on its expression level in a set of given samples. The gene with the lower $M$ value $(M<1.5)$ indicates a higher expression stability [21]. In the evaluation by geNorm, ETIF1a was deemed to be the most stable gene in all specific organs at the flowering and withering stages while $E F 1 A$ was the most stably expressed gene in the rhizomes at various stages. Zhan et al. also used $E F 1 A$ as a reference gene to quantify the expression levels of transcript in leaves and rhizomes of A. flaccida at the flowering stage [8]. $P U B Q$ was ranked as the second and third most stably expressed gene in the rhizomes at the withering and vegetative stage, respectively, although it was ranked as the first most stably expressed gene in the leaves at the vegetative and flowering stages in this study. These confirmed that different methods may give different results because of their different strategies and calculation algorithms $[29,35]$. geNorm is known to be based on a more effective and feasible algorithm for ensuring the optimal stability of reference genes and its results have been widely accepted by many researchers [21]. NormFinder and BestKeeper are best applied to assess the quality of the gene rankings obtained by geNorm [31]. Moreover, the geNorm algorithm can yield the optimal number of required reference genes by comparing the pair-wise variation $(\mathrm{Vn} / \mathrm{Vn}+1)$ values between consecutively ranked genes. The cut-off values are usually recommended to be a default value of 0.15 [30].

We combined the results from the three methods together in this study, which is shown in Table S1. Based on the result by geNorm that two reference genes were sufficient for RT-qPCR data normalization in different organs at various stages, PUBQ and ETIF1a were the most suitable reference genes for the total sample and specific organs in A. flaccida at most stages. However, EF1A was more desirable as a reference gene than ETIF1a in rhizomes at the vegetative stage. Moreover, EF1A in combination with PUBQ could also be used as a reference gene in the rhizomes at the withering stage (Table S1). In addition, the expression of $P U B Q$ was more stable at the vegetative stage than at the other stages whereas the expression of $E F 1 A$ was more stable in the rhizomes than in the leaves. These also confirmed that the expressions of a few housekeeping genes vary in spatial, temporal and environmental-dependent patterns in plants.

\section{Conclusions}

The genes PUBQ and ETIF1a had a stable expression in most organs at different developmental stages of $A$. flaccida. Therefore, they can be used as reference genes for the data normalization in an RT-qPCR analysis of this plant. PUBQ and EF1A were more desirable as reference genes in rhizomes at the vegetative stage and could also be used at the withering stage. This study laid a foundation for understanding the effects of cultivation methods on the biosynthesis of triterpenoid saponins in A. flaccida for future gene expression analysis, which will be beneficial for the development of artificial plantations of this medicinal herb.

Supplementary Materials: The following are available online at https: / /www.mdpi.com/2073-4 425/12/3/459/s1, Figure S1: Agarose gel electrophoresis of raw RNA in different samples. Amplification fragments were separated by $2 \%$ agarose gel electrophoresis. Figure S2: PCR assay for a specificity assessment of qPCR amplification specificity of 10 candidate reference genes. Amplifi- 
cation fragments were separated by $2 \%$ agarose gel electrophoresis. Figure S3: Melting curves of RT-qPCR amplifications of 10 candidate reference genes. Figure S4: Amplification efficiency of 10 candidate reference genes. Table S1: Expression stability ranking of 10 candidate reference genes by using geNorm $(\mathrm{G})$, NormFinder $(\mathrm{N})$ and BestKeeper (B) methods.

Author Contributions: Z.Z., T.Y. and Z.N. wrote the paper; T.Y. conceived and designed the study. Z.Z., H.Z., B.L., Z.Y. and X.L. performed the experiments; X.W. and X.H. provided essential assistance for this study. All authors have read and agreed to the published version of the manuscript.

Funding: This research received no external funding.

Institutional Review Board Statement: Not applicable.

Informed Consent Statement: Not applicable.

Data Availability Statement: The data presented in this study are available in Supplementary Material.

Conflicts of Interest: The authors declare no conflict of interest.

\section{References}

1. Kong, X.Y.; Yang, Y.; Wu, W.B.; Li, X.M.; Zhong, M.C.; Su, X.H.; Jia, S.W.; Lin, N. Triterpenoid saponin W3 from Anemone flaccida suppresses osteoclast differentiation through inhibiting activation of MAPKs and NF-kappa B pathways. Int. J. Biol. Sci. 2015, 11, 1204-1214. [CrossRef]

2. Kong, X.Y.; Wu, W.B.; Yang, Y.; Wan, H.Y.; Li, X.M.; Zhong, M.C.; Zhao, H.Y.; Su, X.H.; Jia, S.W.; Ju, D.H.; et al. Total saponin from Anemone flaccida Fr. Schmidt abrogates osteoclast differentiation and bone resorption via the inhibition of RANKL-induced NF-kappa B.; JNK and p38 MAPKs activation. J. Transl. Med. 2015, 13, 1-12. [CrossRef] [PubMed]

3. Bing, F.H.; Zhang, G.B. National five class of new drugs-Diwu rheumatic analgesic capsule. Hubei J. Tradit. Chin. Med. 2005, 27, 48-49.

4. Zhang, Z.C.; Geng, M.J.; Yang, T.W.; Liu, W.; Wang, J.; Xin, L.; Liu, B.C.; Zhu, D.W. Studies on tissue culture of Anemone flaccida. Chin. Tradit. Herbal Drugs 2010, 41, 1168-1172.

5. Wang, J.; Zhu, D.W.; Yang, T.W.; Liu, B.C.; Yang, R.W.; Geng, M.J. Optimization of multiplication medium for adventitious bud of Anemone flaccida. Pharm. Biotechnol. 2012, 19, 45-48.

6. Xin, L. Effects of Mineral Nutrition on Growth and Medicinal Ingredients of Anemone flaccida Fr. Schmidt. Master's Thesis, Huazhong Agricultural University, Wuhan, China, 2010.

7. Batista, D.S.; Moreira, V.S.; Felipe, S.H.S.; Fortini, E.A.; Silva, T.D.; Chagas, K.; Louback, E.; Romanel, E.; Costa, M.G.C.; Otoni, W.C. Reference gene selection for qPCR in Brazilian-ginseng [Pfaffia glomerata (Spreng.) Pedersen] as affected by various abiotic factors. Plant Cell Tissue Organ Cult. 2019, 138, 97-107. [CrossRef]

8. Zhan, C.S.; Li, X.H.; Zhao, Z.Y.; Yang, T.W.; Wang, X.K.; Luo, B.B.; Zhang, Q.Y.; Hu, Y.R.; Hu, X.B. Comprehensive analysis of the triterpenoid saponins biosynthetic pathway in Anemone flaccida by transcriptome and proteome profiling. Front. Plant Sci. 2016, 7, 1-12. [CrossRef]

9. Zheng, T.C.; Chen, Z.L.; Ju, Y.Q.; Zhang, H.; Cai, M.; Pan, H.T.; Zhang, Q.X. Reference gene selection for qPCR analysis of flower development in Lagerstroemia indica and L. speciosa. PLoS ONE 2018, 13, e0195004.

10. Libault, M.; Thibivilliers, S.; Bilgin, D.D.; Radwan, O.; Benitez, M.; Clough, S.J.; Stacey, G. Identification of four soybean reference genes for gene expression normalization. Plant Genome 2008, 1, 44-54. [CrossRef]

11. Mo, X.L.; Zhou, Z.W.; Ba, Y.C.; Wu, Q.Y.; Lai, Z.X.; Sun, Y. Bioinformatics of phytochrome gene family members of tea, its expression and correlation with flavonoid content. J. South. Agric. 2019, 50, 1173-1182.

12. Li, J.T.; Han, X.P.; Wang, C.; Qi, W.Z.; Zhang, W.Y.; Tang, L.; Zhao, X.T. Validation of suitable reference genes for RT-qPCR data in Achyranthes bidentata Blume under different experimental conditions. Front. Plant Sci. 2017, 8, 1-12. [CrossRef]

13. Zhang, G.; Zhao, M.M.; Song, C.; Luo, A.X.; Bai, J.F.; Guo, S.X. Characterization of reference genes for quantitative real-time PCR analysis in various tissues of Anoectochilus roxburghii. Mol. Biol. Rep. 2012, 39, 5905-5912. [CrossRef] [PubMed]

14. Baud, S.; Wuillème, S.; Dubreucq, B.; De Almeida, A.; Vuagnat, C.; Lepiniec, L.; Miquel, M.; Rochat, C. Function of plastidial pyruvate kinases in seeds of Arabidopsis thaliana. Plant J. 2007, 52, 405-419. [CrossRef] [PubMed]

15. Xiao, X.L.; Ma, J.B.; Wang, J.R.; Wu, X.M.; Li, P.B.; Yao, Y.N. Validation of suitable reference genes for gene expression analysis in the halophyte Salicornia europaea by real-time quantitative PCR. Front. Plant Sci. 2015, 5, 1-11. [CrossRef] [PubMed]

16. Luo, H.L.; Luo, K.C.; Luo, L.P.; Li, E.X.; Guan, B.C.; Xiong, D.J.; Sun, B.T.; Peng, K.; Yang, B.Y. Evaluation of candidate reference genes for gene expression studies in Cymbidium kanran. Sci. Hortic. 2014, 167, 43-48. [CrossRef]

17. Castro, P.; Castro, P.; Román, B.; Rubio, J.; Die, J. Selection of reference genes for expression studies in Cicer arietinum L.: Analysis of cyp81E3 gene expression against Ascochyta rabiei. Mol. Breed. 2012, 29, 261-274. [CrossRef]

18. Huis, R.; Hawkins, S.; Neutelings, G. Selection of reference genes for quantitative gene expression normalization in flax (Linum usitatissimum L.). BMC Plant Biol. 2010, 10, 71-80. [CrossRef]

19. Goossens, K.; Van, P.M.; Van, S.A.; Vandesompele, J.; Van, Z.A.; Peelman, L.J. Selection of reference genes for quantitative real-time PCR in bovine preimplantation embryos. BMC Dev. Biol. 2005, 5, 27-36. [CrossRef] 
20. Gutierrez, L.; Mauriat, M.; Guénin, S.; Pelloux, J.; Lefebvre, J.F.; Louvet, R.; Rusterucci, C.; Moritz, T.; Guerineau, F.; Bellini, C.; et al. The lack of a systematic validation of reference genes: A serious pitfall undervalued in reverse transcription-polymerase chain reaction (RT-PCR) analysis in plants. Plant Biotechnol. J. 2008, 6, 609-618. [CrossRef]

21. Vandesompele, J.; De Preter, K.; Pattyn, F.; Poppe, B.; Van, R.N.; De, P.A.; Speleman, F. Accurate normalization of real-time quantitative RT-PCR data by geometric averaging of multiple internal control genes. Genome Biol. 2002, 3, 12-13. [CrossRef]

22. Andersen, C.L.; Jensen, J.L.; Orntoft, T.F. Normalization of real-time quantitative reverse transcription-PCR data: A model-based variance estimation approach to identify genes suited for normalization, applied to bladder and colon cancer data sets. Cancer Res. 2004, 64, 5245-5250. [CrossRef] [PubMed]

23. Pfaffl, M.W.; Tichopad, A.; Prgomet, C.; Neuvians, T.P. Determination of stable housekeeping genes.; differentially regulated target genes and sample integrity: BestKeeper-Excel-based tool using pair-wise correlations. Biotechnol. Lett. 2004, 26, 509-515. [CrossRef]

24. Czechowski, T.; Stitt, M.; Altmann, T.; Udvardi, M.K.; Scheible, W.R. Genome-wide identification and testing of superior reference genes for transcript normalization in Arabidopsis. Plant Physiol. 2005, 139, 5-17. [CrossRef]

25. Kim, B.R.; Nam, H.Y.; Kim, S.U.; Kim, S.I.; Chang, Y.J. Normalization of reverse transcription quantitative-PCR with housekeeping genes in rice. Biotechnol. Lett. 2003, 25, 1869-1872. [CrossRef] [PubMed]

26. Fei, X.T.; Shi, Q.Q.; Yang, T.X.; Fei, Z.X.; Wei, A.Z. Expression stabilities of ten candidate reference genes for RT-qPCR in Zanthoxylum bungeanum Maxim. Molecular 2018, 23, 802. [CrossRef]

27. Liu, J.; Wang, Q.; Sun, M.Y.; Zhu, L.L.; Yang, M.; Zhao, Y. Selection of reference genes for quantitative real-time PCR normalization in Panax ginseng at different stages of growth and in different organs. PLoS ONE 2014, 9, e112177. [CrossRef] [PubMed]

28. Zhang, J.; Zhu, C.S.; Huo, Y.B.; Zhang, B.; Ma, Z.Q.; Feng, J.T.; Zhang, X. Validation of suitable reference genes for quantitative gene expression analysis in Tripterygium wilfordii. Mol. Biol. Rep. 2019, 46, 4161-4174. [CrossRef]

29. Yue, H.; Deng, P.C.; Liu, S.Y.; Wang, M.; Song, W.N.; Nie, X.J. Selection and evaluation of reference genes for quantitative gene expression analysis in broomcorn millet (Panicum miliaceum L.). J. Plant Biol. 2016, 59, 435-439. [CrossRef]

30. Cheng, T.; Zhu, F.L.; Sheng, J.J.; Zhao, L.L.; Zhou, F.S.; Hu, Z.L.; Diao, Y.; Jin, S.R. Selection of suitable reference genes for quantitive real-time PCR normalization in Miscanthus lutarioriparia. Mol. Biol. Rep. 2019, 10, 4545-4553. [CrossRef]

31. Li, C.Q.; Hu, L.Z.; Wang, X.Q.; Liu, H.Z.; Tian, H.H.; Wang, J.S. Selection of reliable reference genes for gene expression analysis in seeds at different developmental stages and across various tissues in Paeonia ostii. Mol. Biol. Rep. 2019, 46, 6003-6011. [CrossRef]

32. Gonzalez-Aguilera, K.L.; Saad, C.F.; Montes, R.A.C.; Alves-Ferreira, M.; de Folter, S. Selection of reference genes for quantitative real-time RT-PCR studies in tomato fruit of the genotype MT-Rg1. Front. Plant Sci. 2016, 7, 1-8. [CrossRef] [PubMed]

33. Iskandar, H.M.; Simpson, R.S.; Casu, R.E.; Bonnett, G.D.; Maclean, D.J.; Manners, J.M. Comparison of reference genes for quantitative real-time polymerase chain reaction analysis of gene expression in sugarcane (Saccharum sp.). Plant Mol. Biol. Rep. 2004, 22, 325-337. [CrossRef]

34. Nicot, N.; Hausman, J.F.; Hoffmann, L.; Evers, D. Housekeeping gene selection for real-time RT-PCR normalization in potato during biotic and abiotic stress. J. Exp. Bot. 2005, 56, 2907-2914. [CrossRef]

35. Zhong, H.Y.; Chen, J.W.; Li, C.Q.; Chen, L.; Wu, J.Y.; Chen, J.Y.; Lu, W.J.; Li, J.G. Selection of reliable reference genes for expression studies by reverse transcription quantitative real-time PCR in litchi under different experimental conditions. Plant Cell Rep. 2011, 30, 641-653. [CrossRef] [PubMed] 